\title{
Pembinaan Guru Seni Budaya Smpn 3 Dan Smpn 4 Kota Bukittinggi \\ Dalam Pembelajaran Keterampilan Sub Bidang Studi 'Tenun Bergambar
}

\author{
Zubaidah, Erwin, Mediagus, Nessya Fitriyona \\ Dosen Jurusan Seni Rupa FBS UNP Padang \\ Email: zubaidahseni@gmail.com
}

\begin{abstract}
, one of the obstacles in improving the quality of education and learning in schools is the lack of improvement on the quality of teachers. In addition, the limited funds, facilities and infrastructure, is also a cause of the decline in the quality of education. Research Findings Yusmelmeri, S, Pd. Master of Arts Studies at SMPN 4 Bukittinggi (2015/2016) entitled: "The Implementation of Art Learning at SMPN 4 Bukittinggi" proves that the low ability of art teachers in skills / craft learning materials. The conclusion of the study stated that of the five schools in Bukittinggi city that were used as research objects, only one school runs / teaches skill material. Concerns about teachers' inadequacies in this skill learning process require teachers to attend education and training / workshops. Teachers who will be trained are teachers of SMP Arts Culture in Bukittinggi City as many as 10-15 people. The main priorities given to teachers of SMP Cultural Arts who are expected after this training will be: 1) insight and knowledge of weaving images based on competency standards in grade VIII SMP, 2) creating at least one pictorial woven work based on techniques and steps has been studied, and 3) implements it in skills learning in the classes. After the training, the results obtained: teachers SMP Arts Culture city of Bukittinggi: 1) already have insight and knowledge about weaving pictorial based on competency standards in class VIII junior high school, 2) has produced a work of pictorial weaving based on techniques and steps that have been studied. Thus it can be concluded that generally teachers in SMPN Bukittinggi have knowledge of both theory and practice of pictorial weaving. Therefore, it is necessary to have the contini-cy in applying the knowledge and skills acquired by the teachers. If this activity is not done continuously, then the knowledge and skills that have been obtained will be meaningless

Keyword: Pembelajaran Seni Budaya, Tenun Bergambar
\end{abstract}

\section{A. PENDAHULUAN}

Keprofesionalan seorang guru adalah harus mampu menunjukkan kinerjanya dalam melaksanakan tugas profesi kependidikan yang ditandai dengan penguasan kompetensi akademik kependidikan dan penguasaan kompetensi substansi dan/atau bidang studi sesuai bidang ilmunya. Salah satu contoh adalah guru Seni Budaya yang tidak hanya profesional di bidang kesenirupaan tetapi harus menguasai substansi 
bidang keterampilan. Asumsi ini didasari atas standar kompetensi yang harus diajarkan guru seni budaya (seni rupa) pada tingkat satuan pendidikan Sekolah Menengah Pertama (SMP).

Paradigma baru pendidikan Seni Budaya (Seni Rupa dan Keterampilan) di SMPmemiliki peluang yang sangat strategis untuk menyiapkan individu-individu yang kreatif dan inovatif, jika dirancang dan dilaksanakan berdasarkan pendekatan akademis. Selanjutnya,pendidikan seni memberikan toleransi pada lingkungan belajar yang fleksibel, proses pembelajaran yang unik, serta aktivitas dan metode instruksional yang sahih.Pendidikan seni dan keterampilan/kerajinan merupakan seperangkat ilmu yang dapat digunakan guru untuk melatih dan membangkitkan kepekaan estetis agar dapat menghayati pengetahuan dan pengalaman yang diperoleh dalam kehidupan sehari-hari (Pakasi, 2007:60). Maka, hasil pendidikan seni dan keterampilan diharapkan dapat meningkatkan kemampuan menerapkan, mengembangkan, dan menyebarluaskan seni dalam upaya meningkatkan taraf kehidupan sosial dan memperkaya kebudayaan masyarakat.

Berdasarkan hasil pengamatan dan diskusi tim pengabdian kepada masyarakat dengan guru bidang studi Seni Rupa dan Keterampilan di beberapa SMPKota Bukittinggi (12 Desember 2016) bahwa, sebahagian besar guru tidak mengajarkan pembelajaran keterampilan. Artinya, tuntutan standar kompetensi khususnya pembelajaran keterampilan yaitu "Mengapresiasi dan Membuat Kerajinan Tenun Bergambar"(Tenun bergambar), tidak berjalan menurut semestinya. Berdasarkan temuan di salah satu sekolah, bahwa penyebab masalah ini adalah karena para guru lebih mendominasikan pembelajaran seni rupa (apresiasi dan ekspresi). Di sisi lain, kebanyakkan guru kurang memiliki kemampuan serta keterampilan di bidang tenun bergambar ini dengan alasan bahwa latar belakang pendidikan adalah seni rupa bukan keterampilan. Hal ini tentunya secara langsung akan berdampak pada tidak adanya wawasan dan keterampilan yang dimiliki siswa setelah tamat Sekolah Menengah Pertama. Diketahui bahwa tidak semua siswa dapat melanjutkan pendidikan ke jenjang yang lebih tinggi dengan berbagai faktor. Maka, konsekwensinya, siswa tidak dapat hidup mandiri karena tidak memiliki keterampilan yang dapat dikembangkan sebagai bidang usaha.

Menghadapi situasi ini, guru pendidik seni rupa dan keterampilan di Sekolah MenengahPertamaharus memiliki pengetahuan/wawasan dan keterampilan, tidak hanya di bidang seni rupa namun juga keterampilan dan kerajinan. Di samping itu, sebagai guru seni budaya dan keterampilan juga harus memiliki kejelian untuk memilih pendekatan yang dapat mengajak semua siswa untuk berpartisipasi aktif dalam pembelajaran keterampilan dan kerajinan. Sekaligus juga harus dapat mendorong siswa agar mampu meningkatkan kemampuan mencetuskan imajinasi dan gagasan ke dalam bentuk kegiatan keterampilan sesuai dengan kompetensi dasar yang sudah ditetapkan.

Di tengah-tengah keprihatinan terhadap kekurangmampuan guru dalam pembelajaran keterampilan khususnya bidang tenun bergambar, maka tim pengabdian kepada masyarakat mencari beberapa referensi informasi tentang pendekatan pembelajaran yang dapat dipertanggungjawabkan. Untuk itu tim pengabdian mencoba memberikan pengetahuan dan keterampilan khususnya pada standar kompetensi : "mengapresiasi dan membuat benda kerajinan tenun bergambar (tapestry)" kepada guru-guru seni budaya (seni rupa dan keterampilan) di SMP Kota Bukittinggi dengan 
judul: "IbM Bagi Guru Seni Budaya (Seni Rupa) SMP Kota Bukittinggi dalam Mata Pelajaran Keterampilan Sub Bidang Studi Tenun Bergambar melalui Workshop Seni dan Keterampilan". Konsepsi kegiatan workshop seni dan keterampilan ini didasari atas : a) kelangkaan buku teks bidang tenun bergambar sebagai buku acuan wajib bagi guru seni budaya dan keterampilan, b) membekali para guru dengan berbagai keterampilan melalui kegiatan workshop, diyakini akan lebih efektif dan efisien, sehingga sasaran yang diharapkan dapat tercapai secara maksimal, (Permendiknas nomor 2 Tahun 2008). Di sisi lain, hasil riset menunjukkan bahwa cabang ilmu keterampilan dan kerajinan ("craft atau kunstnijverheid") merupakan bagian dari art (seni rupa) yang bila dikembangkan menghasilkan bermacam-macam bentuk benda (Soedarso, 1999). Lebih lanjut dibuktikan bahwa craft atau kerajinan sepadan dengan istilah "kriya" itu sangat berkaitan dengan skill (keterampilan). Kerajinan sebagai benda yang dihasilkan membutuhkan modal rajin dan juga modal skill.

\section{B. METODE PELAKSANAAN}

\section{Metode Yang Ditawarkan}

Metode yang ditawarkan untuk memecahkan masalah adalah dengan menerapkan teknologi tenun bergambar untuk menganekaragamkan jenis dan desain produk kerajinan. Agar tujuan tercapai dengan maksimal, maka beberapa metode yang digunakan adalah :

a. Metode ceramah, digunakan untuk menyampaikan materi yang sifatnya teoritis

b. Metode demonstrasi, digunakan untuk memperlihatkan tentang produkproduk tenun bergambar serta jenis-jenisnya.

c. Metode eksperimen, digunakan dalam rangka memperoleh pengalaman tentang aplikasi teknik tenun bergambarpada beberapa produk kerajinan.

d. Metode pemberian tugas: digunakan untuk memantapkan penguasaan dalam menciptakan kerajinan tenun bergambar sampai kepada keterampilan menempatkan motif pada sebuah produk tenun bergambar (benda pakai dan benda hiasan).

Aplikasi dari metode tersebut dilakukan langkah-langkah sebagai berikut yaitu:

a. Pembuatan Model

b. Minimal dibuat 5 model produk tenun bergambar dengan berbagai jenis bahan sebagai pedoman bagi guru dalam mendesain benda kerajinan.

c. Penerapan materi pelatihan pada guru Seni Budaya Seni Rupa

d. Model yang dibuat dilatihkan kepada guru-guru yang dilibatkan pada pelatihan ini dengan berbagai metode, sehingga para guru dapat memahami prinsip, prosedur serta teknik dalam menciptakan karya tenun bergambar sebagai salah satu standar kompetensi yang harus diajarkan di SMP.

\section{Pelaksanaan Kegiatan}

Kegiatan dilaksanakan selama delapan bulan dengan rencana kegiatan sebagai berikut: 


\section{a. Persiapan}

Kegiatan yang dilakukan pada persiapan ini adalah:

1) Pemantapan jadwal: yaitu penentuan jadwal konkrit bersama mitra setelah usulan kegiatan disetujui untuk dilaksanakan.

2) Kordinasi dengan Dinas Pendidikan Kota Bukittinggi, dan mitra, serta bersama mitra melakukan pengurusan izin pelaksanaan kegiatan.

3) Rekrutmen peserta: rekrutmen peserta dilakukan dengan bekerjasama dengan mitra. Peserta adalah guru-guru mata pelajaran Seni Budaya (Seni Rupa), di SMP Kota Bukittinggi. Jumlah peserta yang dilibatkan dalam pelatihan adalah sebanyak 10 - 15 orang.

\section{b. Pelaksanakan kegiatan}

Pelaksanaan kegiatan ini direncanakan melaui tahap:

1) Persiapan materi pelatihan: yang dipersiapkan adalah media pembelajaran berupa poster dan chart arus sebagai alat bantu dalam memahami prosedur mengerjakan produk kerajinan tenun bergambar. Selanjutnya mempersiapkan bahan dan alat yang digunakan seperti: bermacam jenis benang, kain persca, gunting, ram/pamedangan.

2) Pelaksanaan pelatihan:

Materi yang diberikan sebagai realisasi pemecahan masalah bagi guru Seni Rupa SMP adalah :

a. Pelatihan tentang materi wawasan desain serta pengetahuan tentang bahan dan motif untuk kerajinan tenun bergambar sebagai dasar menyusun rencana pembelajaran keterampilan di SMP

b. Praktik menciptakandesain tenun bergambar: teknik mendesainkarya, menciptakan motif sederhana, stilasi motif alam (tumbuh-tumbuhan dan hewan), menyempurnakan motif melalui warna, dan teknik finishing karyatenun bergambar.

Sebelum dilakukan praktek merancang dan menciptakan motif kriya tenun bergambar, kepada guru dilatihkan teknik membuat motif sederhana melalui sketsa dan contoh-contoh pada media. Latihan ini dilakukan berulangulang hingga para guru/peserta mampu menguasai garis/goresan (garis lurus, lengkung, lingkaran) pada motif yang dibuat. Kemudian dilanjutkan dengan praktek membuat karya tenun bergambar sesuai langkah-langkah yang ada pada gambar/media. Selama proses pengerjaan, peserta dibimbing secara kelompok atau individu oleh para instruktur.

\section{c. Evaluasi dan Monitoring}

Agar dapat mengetahui sejauhmana latihan keterampilan mendesain dan membuat karya kerajinan tenun bergambar ini berhasil, baik secara teknis maupun manfaat yang diperoleh oleh peserta, diadakan penilaian :

1) Melalui uji coba menciptakan bermacam-macam desain, diawal kegiatan.

2) Menciptakan motif dan teknik penempatan motif sesuai dengan desain benda kerajinan tenun bergambarserta kombinasi warna pada karya

3) Evaluasi akhir dengan kriteria : kerapian, kebersihan dan hasil karya. 


\section{HASIL DAN PEMBAHASAN}

\section{Hasil Berdasarkan ProsesKegiatan}

Hasil yang ingin dicapai sesuai dengan tujuan kegiatan adalah untuk meningkatkan kemampuan guru bidang studi seni budaya dalam:

aspek wawasan dan pengetahuan tentang meteri tenun bergambar pada dalam pembelajaran keterampilan di SMP,

mampu menciptakankriya tenun bergambar untuk fungsi hiasan dengan berbagai ukuran sebagai alat peraga di kelas pada saat pembelajaran keterampilan.

Untuk mengetahui ketercapaian tujuan, terlebih dahulu dilakukan penjajakan kemampuan awal peserta pelatihan sebelum kegiatan dimulai dalam bentuk tanya jawab berupa: kemampuan teoritis, yaitu sejauh mana pengetahuan peserta tentang keterampilan tenun bergambar serta kemampuan praktis sebagai salah satu kompetensi yang harus diajarkan di kelas VIII. Kriteria yang digunakan untuk mengukut tingkat kemampuan dan penerapan adalah penguasaan peserta terhadap materi: pengetahuan tentang tenun bergambar, bahan dan peralatan, serta proses kerja secara teoritis dan praktis.

Didapat hasilnya bahwa pengetahuan dan kemampuan praktik peserta pelatihan tentan tenun bergambar sangat rendah, hampir semua pertanyaan tidak dapat dijawab oleh masing-masing peserta. Peserta pelatihan hanya memahami tentang mekrame sebagai salah satu ketermpilan simpul menyimpul dengan menggunakan benang/tali.

Sehubungan dengan masih rendah pengetahuan secara teori peserta terhadap materi ajar keterampilan khususnya materi tenun bergambar, maka diyakini penerapan (praktiknya) juga rendah dan bahkan tidak mampu mengajarkannya sesuai tuntutan kompetensi.Selanjutnya, dilakukan pelatihan yang diawali denganpenyampaian materi teori tantang karya tenun bergambar, sehingga terlihat kemajuan pemahaman peserta pelatihan terhadap materi sajian. Hasil penilaian yang dilakukan secara lisan dan tanya jawab, hampir seluruh pertanyaan dapat dijawab dengan benar oleh peserta. Untuk itu dilakukan pembinaan melalui pelatihan terhadap masalah yang dihadapi guru dalam pembelajaran keterampilan tapestri melalui beberapa tahap seperti gambar berikut ini:

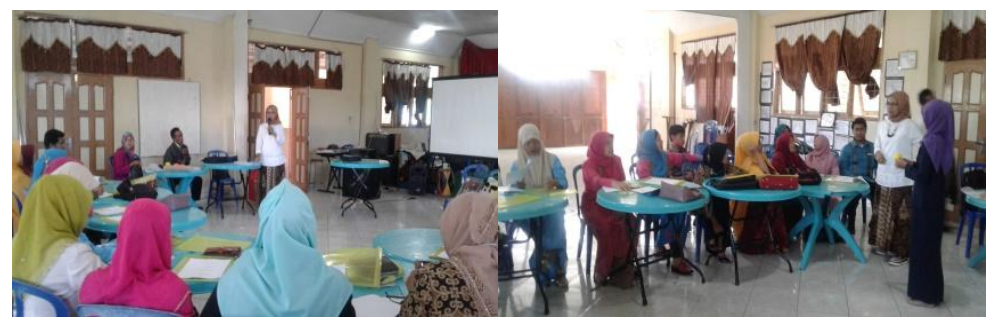

Gbr 1. Penyampaian Materi Pelatihan

Tahap berikutnya adalah kegiatan praktikum dimaksudkan untuk menerapkan pengetahuan yang didapatkan peserta ke dalam produk nyata. Praktikum dilakukan dengan bimbingan individual. Peserta melakukan kegiatan praktikum diarahkan 
kepada teknik membuat bermacam corak tenun bergambar hingga produk jadi. Berikut adalah foto kegiatan praktikum selama pelatihan dan hasil yang didapatkan

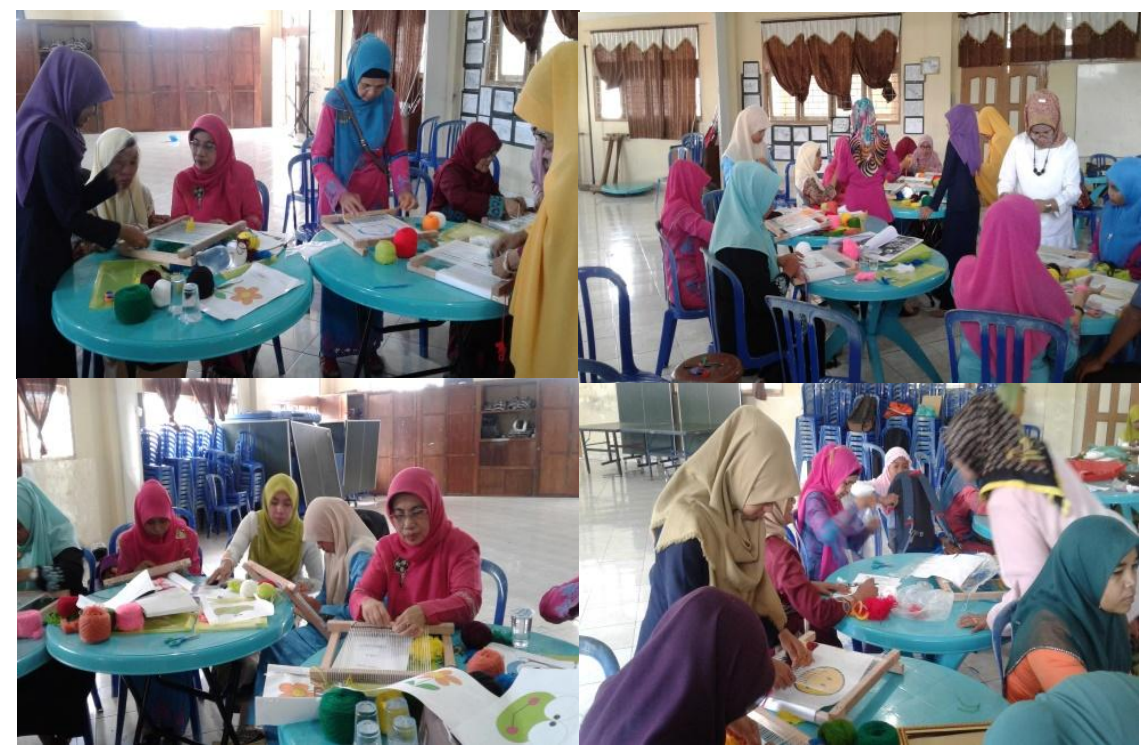

Gbr 2. Peserta sedang praktik menenun karya tenun bergambar

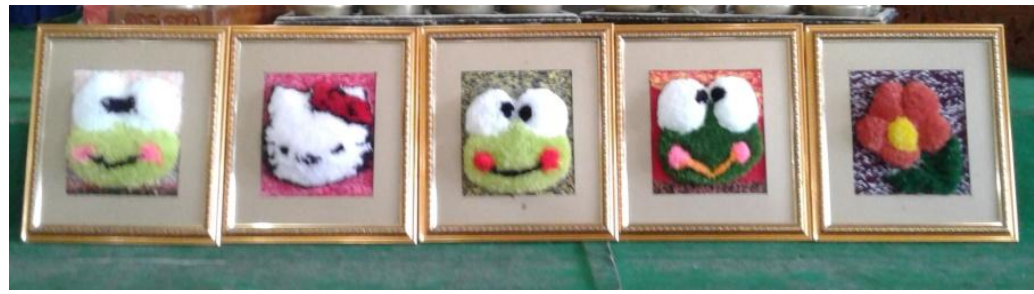

Gbr 3. Hasil karya tenun bergambar dari peserta

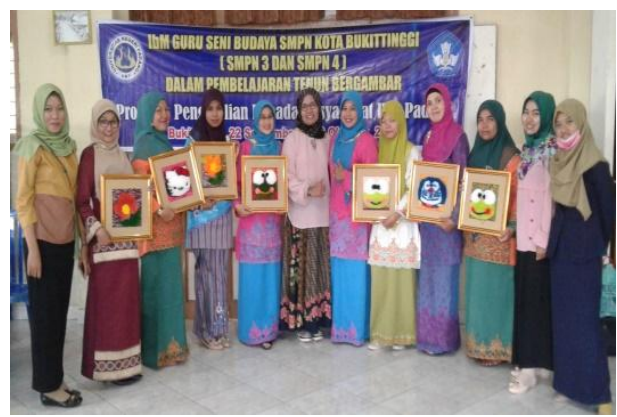

Gbr 7. Hasil Karya Tenun Bergambar dan Foto Bersama

Foto-foto di atas menggambarkan, bahwa kegiatan pelatihan telah berjalan dengan baik dan menghasilkan produk sesuai dengan yang ditargetkan. Masingmasing peserta telah menghasilkan karya tenun bergambar dengan kualitas dan fungsi yang sangat memuaskan. Sekaligus karya peserta dapat dijadikan media/alat peraga di kelas dalam pembelajaran keterampilan sub bidang studi tenun begambar. 


\section{Pembahasan}

\section{a. Pemahaman Materi Pelatihan}

Kemampuan awal peserta pelatihan dalam memahami karya tenun bergambar terlihat masih rendah. Hampir semua pertanyaan tentang pengetahuan karya tenun bergambar yang diajukan tim pelaksana tidak bisa dijawab oleh peserta. Pertanyaan yang bisa dijawab hanya terkait dengan kerajinan anyam menganyan dan simpul menyimpul. Sementara pertanyaan tentang tenun bergambar, teknik dan produknya tidak bisa dijawab. Hal ini menggambarkan bahwa kemampuan pemahaman peserta dibidang tenun menenun sangat rendah. Apalagi dengan bahan dan peralatan yang diperlukan tidak diketahui sama sekali oleh peserta.

Setelah dilakukan penyampaian materi pelatihan, terlihat kemajuan yang berarti dalam memahami materi teori tenun bergambar. Peserta pelatihan juga sudah dapat membedakan materi, teknik tenunan, dan proses penyempurnaan karya. Di samping itu, peserta pelatihan juga dapat memahami dan mengerjakan teknik finishing karya dengan proses pembingkaian.

\section{b. Penerapan}

Pada saat praktikum, peserta pelatihan telah dapat menerapkan pengetahuan yang didapat ke dallam sebuah produk kriya tenun bergambar berupa hiasan dinding. Tingginya tingkat pemahaman peserta disebabkan karena materi yang relatif mudah untuk mencapai tujuan serta penyajian oleh tim pelaksana (instruktur) disertai dengan media proyektor melalui power point, sehingga mudah dipahami dan proses kerja dapat diikuti sesuai tahap-tahapnya. Dengan demikian dapat disimpulkan, bahwa kegiatan telah berhasil dilaksanakan secara baik, dan target luaran sudah tercapai dengan sempurna. Pesertapun bangga dan merasa puas dengan hasil kerjanya masing-masing yang ditunjukkan dengan produk Kriya Tenun Bergambar sebagai media pembelajaran di sekolah.

Pencapaian tujuan sudah membuahkan hasil, yaitu berupa :

1) Peningkatan wawasan dan pengetahuan peserta dalam bidang tenun bergambar.

2) Kemampuan menerapkan teori yang didapat kedalam bentuk produk kriya terapan dua dimensi berupa hiasan dinding dari tenun bergambar .

3) Penguasaan peserta terhadap penggunaan bahan dan peralatan tenun bergambar

Dampak jangka pendek adalah tercapainya tujuan kegiatan, sedangkan dampak terhadap peningkatan kualitas mengajar guru di kelas khususnya dalam materi tenun bergambar belum dapat digambarkan dalam laporan ini, karena peserta belum mengaplikasikannya dalam pembelajaran.

\section{B. SIMPULAN DAN SARAN}

\section{Kesimpulan}

Berdasarkan hasil pelaksanaan kegiatan pelatihan dapat disimpulkan: 
Terjadi peningkatan wawasan dan pengetahuan Guru Bidang Studi Seni Budaya (Seni Rupa/Keterampilan) di Kota Bukittinggi tentang tenun bergambar berdasarkan pengertian,dan jenis produk kriya tenun bergambar,dan macam-macam bahan yang dapat digunakan. Sebelum kegiatan dilakukan, hampir seluruh pertanyaan tidak dapat dijawab peserta. Namun, setelah dilakuka pelatihan, terjadi peningkatan kemampuan yang sangat tajam, sehingga diakhir kegiatan teori, seluruh pertanyaan dapat dijawab peserta.

Terjadinya peningkatan kemampuan Guru Bidang Studi Seni Budaya Seni Rupa di Kota Bukittinggi dalam menerapkan bermacam-macam teknik tenun bergambar dalam kegiatan nyata yang menghasilkan produk. Setiap peserta telah mampu membuat karya tenun bergambar dua dimensi berupa hiasan dinding.

\section{Saran} berikut:

Berdasarkan kesimpulan di atas, perlu disarankan beberapa hal sebagai

Guru Bidang Studi Seni Budaya SMP Kota Buklittinggi dapat memahami, mengaplikasikan pengetahuan yang didapatkan selama pelatihan untuk: bahan pembelajaran keterampilan sub bidang studi tapestridi sekolah.

Guru Bidang Studi Seni Budaya SMP Kota Bukittinggi dapat menciptakan sebuah karya seni murni atau terapan dari teknik tapestri yang dapat digelar/dipamerkan. Perlu adanya kegiatan pengabdian berikutnya yang diutamakan pada guru SMP yang berlatarbelakang pendidikan non seni rupa agar dapat eksis dalam menjalankan pembelajaran seni rupa dan keterampilan sesuai tuntutan sebagai guru profesional.

\section{DAFTAR RUJUKAN}

Anas, Biranul. 2006. Seni Serat Biranul Anas. Jakarta: Art Fabric.

BSNP. 2008. Standar Penilaian Buku Teks Mata Pelajaran Keterampilan. Jakarta: Depdiknas.

Sachari, Agus. 2006. Seni Rupa \& Desain, Standar Isi KTSP 2006. Jakarta: Erlangga

Sahman, Humar. 1993. Mengenali Dunia Seni Rupa. Semarang: IKIP Semarang Press.

Sakri, Adjat. 1990. Pendidikan Seni Rupa. Buku Guru: Jakarta: Departemen Pendidikan dan Kebudayaan

Undang-Undang Nomor 14 Tahun 2005 tentang Guru dan Dosen

Undang-Undang Nomor 20 Tahun 2003 tentang Sistem Pendidikan Nasional 